\title{
Boris Vasil'evich Skvortzov (1896-1980): Notes on his life, family and scientific studies
}

DAVID M. WILLIAMS ${ }^{1}$, MARIA GOLOLOBOVA ${ }^{2} \&$ ELENA GLEBOVA $^{3}$

${ }^{1}$ Department of Life Sciences, the Natural History Museum, Cromwell Road, London, UK

${ }^{2}$ Faculty of Biology, Moscow State University, Lenin Hills, Moscow, Russia

${ }^{3}$ Editorial Office of Journal “Strastnoy Buolevard, 10”, Strastnoy Buolevard, Moscow, Russia

Correspondence to: David M. Williams; e-mail: dmw@nhm.ac.uk 
Abstract

A short account of the life of Boris Vasil'evich Skvortzov (1896-1980) is presented. Some details of his background, his family and his legacy are documented. A short summary of his achievements are included.

Keywords: Boris Vasil’evich Skvortzov (1896-1980)

Running head: Boris Vasil’evich Skvortzov 


\begin{abstract}
"The past becomes destroyed and broken so much that sometimes it is not possible to understand what it meant or represented based on a few surviving fragments. Under these circumstances any surviving fragments become more valuable because they represent a part of the past that may be of interest to everybody who considers themselves to be a man of culture, and considers the present to have an intrinsic organic link to the past”

(Skvortzov, V., unpublished).
\end{abstract}

The epigraph above is taken from a manuscript written by Vasiliy Alexandrovich Skvortzov (Fig. 1). The manuscript, completed in Harbin, China at the end of 1937, charts the genealogy of his family; never intended for publication, it was written only for his descendants. Four copies were made, one for each of his two sons and two daughters. The following discussion focuses on the fate of just one of Vasiliy's children, his son Boris Vasil'evich Skvortzov (1896-1980), a well-known $20^{\text {th }}$ century botanist, who specialised in the study of diatoms (Bacillariophyta) but wrote a great deal more about many aspects of botany (see Baranov 1966, Williams \& Reid 2001).

During his long career, Boris Skvortzov described well over 1500 diatom taxa from over 50 genera (Gololobova 2012: 612—3, Table 1) earning him seventh place in the list of "algal taxonomists that have described more than 1,000 species” (De Clerck et al. 2012: Table 1; Skvortzov’s names include a number of non-diatom algal taxa).

In this account, we will not discuss Skvortzov's contributions to diatom studies in any detail but simply deal with some aspects of his family and a few episodes in this somewhat eventful life.

\title{
What’s in a name? ‘Скворцов, Борис Васильевич’: ‘Skvortzov, Boris Vassilievich’, 'Skvortzow, Boris Wassilievich', 'Skvortsov, Boris Vasil'evich'
}

Even a cursory glance at Skvortzov's many publications yields an immediate problem given that he is referred to, and refers to himself, by several different transliterations of his name. Most commonly he appears as 'Skvortzov, B.V.' but frequently it is alternatively spelt 'Skvortzow' and often with 
the initials B.W. (the latter for 'Wassilievich’). Other variants are Skvorcov (Skvortzov 1917a: 19), Skvorčov (Skvortzov 1917b: 128) and 'B.V. Skvortsoff' (in the Review of the Manchuria Research Society, October 1926: 4, 13, 23, 32; in the issue for 1928 he is referred to as Skvortzow, B.V. and Skwortzow). In Taxonomic Literature (2: 642), the standard botanical author reference work (now online), he is listed as 'Skvortzov [Skvortzow] Boris Vasilevich' and the online International Index of Plant Names Index offers a variety of spellings with ‘Skvortzov, Boris Vassilievich’ and 'Skvortzow, Boris Wassilievich’ given as alternatives to the preferred, and most correct transliteration, Boris Vasil'evich Skvortsov, as it is Skvortsov (ц - ‘ts’) rather than Skvortzov (3 'z'), and thus follows the British Standard for Transliteration of Cyrillic and Greek Characters: B.S. 2979, 1958.

Searching the CAS Catalogue of Diatom Names, On-Line Version yields 57 publications using either 'Skvortzov' or 'Skvortzow' as the search item but yields none when using 'Skvortsov'. Matters differ a little when using Algaebase with 81 publications found when the search item used is 'Skvortzov', 10 for 'Skvortzow' and none for 'Skvortsov'1 . In spite of Skvortsov being the correct transliteration it seems prudent to retain ‘Skvortzov, Boris Vassili’evich’ as this is how he appears on most of his publications, how he is known by most working taxonomists, and how he has signed his name on most items of correspondence and manuscripts (see, for example, Gololobova and Kulikovskiy 2012: Photos 1—3, and the correspondence and manuscript items listed below). In some respects the situation is similar to Anastasiia Panteleimonovna Zhuze (1905-1981) who is known by the transliterated name of A. P. Jousé (Mukhina et al. 2005).

\section{Documentation}

On several occasions, especially in his later papers, those published when he was living in Brazil, Skvortzov supplied pertinent autobiographical details, the lengthiest account being published in

\footnotetext{
${ }^{1}$ It must be remembered that Algaebase covers all of the various algal groups, several of which Skvortzov published on.
} 
1970 as a prelude to a list of his own publications up to 1970 (Skvortzov 1974). A summary, with a few additional details, was included in a letter he sent to Greta A. Fryxell (Skvortzov, B. - Fryxell, G. 1974; a photocopy of this letter is held in the NHM, London). Williams \& Reid (2001) summarised some aspects of Skvortzov's life and work; an even briefer account is found in Taxonomic Literature (2: 642); Baranov wrote an obituary published in 1984 (Baranov 1984) and a very short obituary appeared in Taxon (Anonymous 1980). An earlier account published by Skvortzov is probably not immediately accessible to most people, and we have therefore translated an excerpt (Skvortzov 1946: 1, see Coda below).

The history of the Skvortzov family has previously been discussed in two articles (Glebova 2009a, 2009b). Two items that apparently dealt with Skvortzov’s scientific life were noted in Williams \& Reid (2001) but still no copies of either have been traced (Baranov 1959, Uedo 1940). Some archival material is retained in the NHM, mostly correspondence between Boris and Robert Ross (1912 - 2005, see Cox et al. 2006, Williams 2011), at that time diatomist at the NHM, soon to become its Keeper (Head) of Botany (1966-1977). This material is listed at the end of this paper.

\section{The Skvortzov Family}

We begin with a few words about the origin of Boris’s family as documented in his father's manuscript. The Skvortzov family name was first recorded in 1790, appearing in a list of citizens of the Cossack settlements of Gorodoforpostinskaya in front of the town of Astrakhan, on the right bank of the Volga River. The family name 'Skvortzov' is derived from the Russian word "skvorets” translated as "starling”, the bird.

The founder of this noble family was Boris’s great-grandfather, Vasiliy Filippovich Skvortzov

(Fig. 2), a Cossack captain of Astrakhan Cossack Army from 1801 to 1812. In 1816, Emperor Alexander $1^{\text {st }}$ of Russia granted Vasiliy’s family their coat of arms (Fig. 3). 
Boris’s father, Vasiliy, was born in 1856 in the village of Kopanovskaya (Astrakhan region). He graduated from the Department of Law of St. Petersburg University and in 1880 served in the Life Guards of the Cossack Ataman Regiment, passing their exams and receiving a commission for officer rank. The fate of military men at that time was continuous travel: Vasiliy Skvortzov first served in Astrakhan, then Warsaw, followed by Vladivostok, where he was sent as a prosecutor of the District Court. In 1902 Vasiliy was assigned to Port Arthur (now known as Lüshunkou in China) and then to Harbin (now the capital of Heilongjiang China), where he was the chairman of the County Court until 1920, before the elimination of Russian judicial institutions in Harbin by the Chinese government. In short, Vasiliy Skvortzov was an outstanding person in Harbin and started the Manchurian line of the Skvortsov family (Fig. 4).

\section{Boris V. Skvortzov and his family}

Rather than in Harbin, Boris was born in Warsaw on the $27^{\text {th }}$ January $1896^{2}$ when Vasiliy was posted there during his time in the Russian Army as a judge (Skvortzov 1974). The family moved to Harbin, where Boris spent his childhood and youth; here he was taught at the private school founded by V.L. Anders ${ }^{3}$. In Harbin, Boris worked in his father's garden growing different kinds of plants and as a consequence developed an interest in the local flora putting together his own herbarium and learning to use the microscope (Skvortzov 1974).

After graduating from high school in 1914, Boris was admitted to the Department of Natural Science of Physico-Mathematical Faculty of St. Petersburg University (Fig. 5). It was here that he encountered his “first diatom teachers [who] were Dr. Kolbe ${ }^{4}$ and S.M.Wislouch" ${ }^{5 \text { ” }(S k v o r t z o v}$ 1974,

\footnotetext{
${ }^{2}$ The International Plant Names Index provides a birth date of 1890, which is incorrect. We informed them of this and the entry will be corrected in due course (http://www.ipni.org/ipni/authorsearchpage.do).

${ }^{3}$ Valentin Lyudvigovich Anders (1879-1942) was born in the Amur region. In the early $20^{\text {th }}$ century he established the first male private school in Harbin. It functioned in accordance with classical programme of the Russian Ministry of Education.

${ }^{4}$ Robert Wilhelm Kolbe (1882-1960) (Selling 1962).
} 
Skvortzov - Fryxell, $17^{\text {th }}$ October 1974). While studying at St. Petersburg University, Boris returned to Harbin several times. These trips would have been no mean feat, given that St. Petersburg and Harbin are around $6000 \mathrm{~km}$ apart. For a good deal of its early $20^{\text {th }}$ century history, Harbin would have been a city in turmoil, with, amongst other things, the Russian-Japanese war of 1904—1905 and the fluctuation and increase of the population as a result of Russia's internal conflicts in 1917. It is a wonder how any scientific research could have been undertaken. But when he returned, Skvortzov made natural history collections, studied some of the algae from the lowlands of the Sungari (Songhua) River and produced a series of papers on the algal flora of Asiatic Russia ('Materialy po flory vodoroslej Aziatskoj Rossii'; 'Contributions à la flore des algues de la Russie d’Asie', Skvortzov 1917a, b, 1918).

It was in St. Petersburg that Boris met Nikolai Vavilov (1887-1943), the renowned botanist and geneticist (Harland 1954); they became friends and continued their correspondence until Vavilov’s untimely death in 1943 (Pringle 2008). Vavilov developed ideas on the centres of origin of cultivated plants (Vavilov 1926; for a fuller account of Vavilov’s ideas see Harris 1990), which eventually bought him into conflict with Trofim Lysenko (1898-1976) whose non-Mendelian approach to genetics found favour with Joseph Stalin (Graham 2016). The conflict resulted in Vavilov's arrest, imprisonment and death sentence (which was commuted), but he eventually died in prison from starvation. One might be tempted to speculate on the nature of the discussions between Skvortzov and Vavilov, given Skvortzov's own interest in explaining the distribution of diatoms in Lake Baikal (Skvortzov 1937a: 294-295). Skvortzov refers to Leo (Lev) Berg, with whom he had a meaningful interaction (see Williams \& Reid 2005 for a fuller discussion of Berg and Skvortzov in relation to diatom distributions), and Berg and Vavilov would almost certainly have discussed issues related to ‘centres of origin’ in biogeography. Shaw \& Oldfield (2015) have commented on the

\footnotetext{
${ }^{5}$ Stanislav [Stanisław] (Michaelovic) Wisłouch (1875-1927), a Polish phycologist who published several papers on diatoms (Siemińska 2007: 31, fig. 7 for a portrait), including a number of studies co-authored with Kolbe (Wisłouch and Kolbe 1916, 1927).
} 
relationship between Vavilov and Berg: “Among the geographers and their associates the most prominent victim was the major geneticist Nikolai Vavilov, friend of Berg and president of the Geographical Society between 1931 and 1940. Vavilov was arrested in 1940 as a result of his rivalry with the scientific fraudster, Trofim Lysenko, and perished in prison in Saratov in 1943” (Shaw \& Oldfield 2015: 42). Interestingly, and admittedly at a tangent, Berg crossed swords with the exceedingly unpleasant Merezchowsky: "In fact, famed biologist, ichthyologist and physical geographer, Lev Simonovich Berg (1876-1950) a founder of limnology in Russia was prevented from obtaining a Chair at Kazan University after Merezhkowky’s public denunciations. Berg was a Jew, and Merezhkowsky hated him. Between 1908-1909 there was a conflict between those who wanted to make Berg Professor of Geography of Kazan University and those who, like Merezhkowsky protested against Berg because he was a Jew” (Sapp et al. 2002: 428).

In 1917, at the beginning of the Russian revolution, Boris returned to Harbin from St. Petersburg (Fig. 6). There he taught the students at the School of Commerce of the Chinese Eastern Railway but was also occupied with various scientific research activities. During his time in Harbin, Boris collaborated with the Manchurian Agricultural Society, Society of the Study of the Manchurian region, the Harbin Society of Naturalists and Ethnographers (many photographs of him can be found in various issues of the Review of the Manchuria Research Society ${ }^{6}$ ). He also worked at the Harbin Museum and the Sungari River Biological Station. In 1918 he spent a year studying English in Foochow, Fukien, China where his sister, Olga Myers, lived (Skvortzov 1974, Skvortzov - Fryxell $17^{\text {th }}$ October 1974).

Later, Boris began his own family. With his wife Zinoviya Petrovna (Fig. 7), they had two daughters (Tatiana and Olga) followed by a son, Alexander (Figs 8, 9). Both of his daughters graduated from high school in Harbin, and both re-located to São Paulo, Brazil. One, Tatiana

\footnotetext{
${ }^{6}$ This is the transliterated title of Otdêl'noe Izdanie. Obshchestvo Izucheniyà Man'chzhurskogo Kraiyà, issues examined were published from 1925—1928.
} 
Skvortsova (Sendulsky after marriage ${ }^{7}$ ), became a botanist working at the Botanical Institute in São Paulo and dealt with higher plants (Gramineae), while Olga, his other daughter, dedicated her life to her family, raising children and grandchildren.

Alexander, his son, was born in 1932 and due to illness was educated at home until he was four years old, after which he attended the Russian school in Harbin. During World War II, life was difficult for the family because Boris lost his primary job in the Museum of Regional Studies. But he was not idle: he harvested medicinal plants and passed them to Russian pharmacies; he grew seedlings and was engaged in subsistence farming.

The fate of Boris’s son, Alexander, was tragic. In October 1950 Alexander did not return from school. As it turned out, he was arrested by the Chinese police and spent about a month in a Chinese prison. He was then transferred to the Soviet $\mathrm{NKVD}^{8}$ and deported from China to the USSR. Here Alexander was sentenced to five years in a forced labour camp, situated in Svobodlag in the Amur region. During this time, Boris knew nothing of his son. After Stalin’s death, Alexander was granted amnesty and released from prison. He subsequently settled in Khabarovsk (close to the borders of China) and became a meteorologist.

For Alexander, communication with his family was only made possible in 1955. Alexander wanted his family to move from Harbin to Khabarovsk (by that time both of his sisters Tatiana and Olga had already moved to São Paulo, Brazil). Alexander wrote to his father that the Institute of Agriculture was established in Khabarovsk, and it was possible he could get a job there. But Boris had stopped replying to his son's letters as he did not want to return to the USSR, now a country completely foreign to him. But Boris knew that a direct refusal could be harmful to his son who wished to remain in the USSR. Boris had not forgotten the sad fate of his friend Nikolai Vavilov and

\footnotetext{
${ }^{7}$ Tatiana Sendulsky (1922_2004, see Hoehnea 31(3) and Filgueiras 2004: 5).

${ }^{8}$ NKVD (Narodnyy Komissariat Vnutrennikh Del) is the secret police agency in former USSR from 1934 to 1946.
} 
so only resumed correspondence with his son after he moved to Brazil. Alexander never met his parents again, it was only in 1990 that he was able to visit his elder sisters in Brazil.

By the end of the 1950s and early 1960s, Russians began to leave Harbin due to the prevailing situation with China. Boris eventually left Harbin as well, in 1962 (the dates of his travels can be traced via the correspondence with R. Ross detailed below in the Manuscript Material section). At the time of his departure to São Paulo, Boris was a Professor of the Forestry Academy of Harbin and a researcher at the Institute of Forestry of the Chinese Academy of Sciences. The Chinese realized how much Boris was of value to their country and bestowed honours on him. When he departed he was even allowed to take his library. To avoid any trouble (there was little sympathy with emigrants at that time), he was escorted by some Chinese colleagues to the Hong Kong border and provided with much assistance.

Circumstances had forced Boris to depart for another country and to abandon his family graves at the Uspenskoe Russian cemetery in Harbin. After some years, the Chinese government removed the asphalt from the Uspenskoe cemetery and built an amusement park in its place. All that remains are some photographs of ruined headstones, images miraculously made by Nikolai Zaika, one of the last Russians in Harbin (Fig. 10).

After his arrival in Brazil, Boris had a position in the cryptogamic section of the Botanical Institute of São Paulo (Fig. 11). It was here that he started to study flagellates in more detail, as it was part of the remit of the Institute while diatoms were not. He managed to describe more than one thousand new species from about 150 genera. He assembled a large collection of phycological samples from Brazil and other countries: USA, Greenland, tropical Asia, South Africa, Australia, New Zealand and Europe.

Skvortzov’s life in Brazil was hard as at the beginning of the 1960s he had no salary. He even tried to sell his library and collections to get money for food (Skvortzov, B. - Fryxell, G. 1974). He was partly supported by his daughters. Today Boris’s son Alexander still lives in Khabarovsk; both 
his sisters have since died. His wife died in Sao Paulo on the $12^{\text {th }}$ June 1969 and Boris died on the $25^{\text {th }}$ June 1980 .

\section{Boris Skvortzov’s Scientific Studies}

We do not intend to discuss at any length Skvortzov's contributions to diatom studies, save to note that he was an exceedingly active and productive researcher, publishing over 400 scientific papers, 87 of which dealt with diatoms, 59 of which included descriptions of new taxa (Williams \& Reid 2001, Gololobova 2012). In all, Boris described 1517 diatom taxa belonged to 55 genera (Gololobova 2012: 613, Table 1). Unfortunately most of the material on which these descriptions were based appears to have been lost, and it is often difficult to study many of his taxa further as the published descriptions were often very brief and the published drawings relatively simplistic.

In the 1960s, Skvortzov had written that “...before [my] departure to Brazil more than 1,000 diatom samples in 30\% formalin solution were left in the Herbarium of the N. E. China Forestry Academy in Harbin” (Skvortzov 2012: 751). At the same time, he wrote that all of his slides (amounting to several thousand!) were sent to the Swedish Embassy in Peking for their eventual deposition in the Department of Palaeobotany in Swedish Museum of Natural History (Skvortzov $1974^{9}$ ), but no such material has ever been located. Some material was sent to various colleagues (“...boxes with dry diatoms samples also have been send [sic] to Dr. R.W. Kolbe..., to Dr. F. Hustedt...and to Dr. R. Ross...”) (Skvortzov 2012: 751) and are still available for study ${ }^{10}$. Thus, it remains to be noted that study of Skvortzov's taxa requires a measure of interpretation and the

\footnotetext{
${ }^{9}$ The same details can be found elsewhere in Skvortzov's writings (e.g. Skvortzov and Node 1971: 3)

${ }^{10}$ Various notes are scattered throughout the literature dealing with the fate or whereabouts of Skvortzov's apparently vast collection. Early on Charles Reimer noted that "Attempts to secure holotype or type material from Skvortzov have been unsuccessful. In a letter recently received by Dr. F. Hustedt, Skvortzov mentioned that his prepared materials had been destroyed in China” (Reimer 1959: 2). Armed with that information, Reimer took the only course possible and designated neotypes but Skvortsov's material does appear every now and then, as, for example, several of the collections that he used for the Lake Baikal studies reside in Bremerhaven (Williams 2004).
} 
propositionof neotypes, rather than just ignoring what amounts to a large body of work in geographical areas now no longer in the same condition as they were when first collected.

\section{Coda}

There is still much to be learnt from Skvortzov's work, not least from collating and deciphering his locality details (Williams \& Reid 2001), attempting to understand the taxon descriptions he provided (Gololobova 2012: 612—3, Table 1) and disentangling the somewhat complex nomenclature that has arisen from the multiple publication of the same name at different times (Skvortzov 2012). With some effort, these are achievable.

We close, then, with two items. First, a few words from Skvortzov on his difficult life, written by him, concerning the terrible circumstances which made his research work complicated to undertake. What follows is an English translation of the introduction to an article he wrote in 1946 (Skvortzov 1946: 1).

\footnotetext{
"This work could not be published for a number of years because of the precarious events started by the Japanese in Manchuria and the Far East. Due to these military adventures, from 1931 to 1945 Manchuria was cut off from the whole cultural world. Communication with the scientific centres in the USSR has been disrupted for more than 15 years ago. Organized by Russians, the well-known Society for Studies of the Manchurian region in the city of Harbin, where the author worked, was forcibly closed and the Russian Society members dispersed. This happened in 1928. Several of the author's manuscripts were lost at the Museum of the Society, as some parts were burned in the fires of the raging war. For these reasons, the present work contains: 1) Descriptions of new species from the Flagellatae group, established in 1931 but never published; 2) Descriptions of new Diatomaceae of the freshwater Tertiary deposits from North China, published in the Bulletin of the Geological Committee of China in $1937^{11}$; descriptions of these new species are repeated due to the fact that the issue, where the work was printed, was almost completely lost in a fire during the occupation of the city of Nanjing by Japanese troops; 3)
}

\footnotetext{
${ }^{11}$ Skvortzov (1937b); this paper can now be accessed at http://onlinelibrary.wiley.com/doi/10.1111/j.17556724.1937.mp17002006.x/pdf
} 
Descriptions of new Diatomaceae from the vicinity of Suzhou, the manuscript... was lost in a fire in the

University of Suzhou during the occupation of this city by Japanese troops ${ }^{12}$; and finally, 4) Descriptions of new fossil Diatomaceae from South Africa. This manuscript was probably lost on the way in the beginning of the Abyssinian War”.

Finally, some words written in appreciation by Boris’s daughter, Tatiana, published shortly before she died in a caption to her own portrait:

“Tatiana standing before a flowering clump of Merostachys skortzvoii [sic, Merostachys skvortzovii ${ }^{13}$ ] Sundulsky...first discovered by Prof. Skvortzov. Tatiana named it after the collector, her much-admired and beloved father” (Filgueiras 2004: 5).

\section{Acknowledgements}

Our grateful thanks to the many useful comments and suggestions from an anonymous reviewer and from Dr Irina Belyaeva-Chamberlain (Kew) for advice and guidance on accepted methods of transliteration.

\section{References}

ANONYMOUS 1980. Boris Vasil'evich Skvortzov Taxon 30: 561.

BARANOv, A.I. 1959. Russkie kraevedy v Man'chzhurii. (B. V. Skvortzov I ego nauchnaia rabota). [Russian regional specialists in Manchuria (B.V. Skvortzov and his scientific work). Sbornik Kharbinskogo Kommercheskogo Uchilischa [Collection of works ‘Harbin Commercial School'] Fasc. 6: 47-49. San Francisco, California (Mimeographed) [Not seen].

\footnotetext{
${ }^{12}$ Skvortzov wrote of this fire in 1971: "The university during the advance of Japanese army to Soochow was burned...” and he went on to note that "The present manuscript [Skvortzov 1971] is the third one..." (Skvortzov 1971: 59). Although Skvortzov (1971) has not been examined in the CAS online diatom name catalogue (accessed 21/3/2016), all the names included were already described in print in Skvortzov (1946).

${ }^{13}$ This species is a bamboo endemic to the Sao Paolo region.
} 
BARANOV, A.I. 1966. Publications of A. I. Baranov - 1940-1965. Taxon 15: 265-269.

БАРАНОВ А.И. 1984. Б.В. Скворцов (1896-1980) (Некролог). Политехник (Австралия) 11: 31. [Baranov, A.I. (1984). BV Skvortsov (1896-1980) (Obituary). Polytechnic (Australia) 11: 31].

CoX, E.J., SiMS, P.A. \& Williams, D.M. 2006. Robert Ross (1912-2005). Diatom Research 21: 479-488.

De Clerck, O., Guiry, M. D., Leliaert, F., SAmyn, Y. \& Verbruggen, H. 2013. Algal taxonomy: a road to nowhere? Journal of Phycology 49(2): 215-225.

FILGUEIRAS, T.S. 2004. Sending warm wishes to Tatiana Sendulsky. Bamboo: The Magazine of the American Bamboo Society 25(4): 5.

GLEBOvA, E. 2009a. Rod Skvortsovikh. Kharbinskaya rukopis'. [Family Skvortsov. Harbin manuscript]. Slovesnitsa Iskusstv 24: 100-111 [In Russian].

GLEBOVA, E. 2009b. Uzor iz rodoslovnikh nitey. [Ornament of family tree branches]. Slovesnitsa Iskusstv 24: 112-117 [In Russian].

Gololobova, M.A. 2012. Checklist of Boris V. Skvortsow's diatom taxa. Iconographia Diatomologica 23: 611-742.

Gololobova, M.A. \& KulikovskiY, M.S. 2012. New and little known fresh- and brackish water diatoms chiefly from Eastern part of Asia and their geographical distribution. A hitherto unpublished article by Boris V. Skvortzow. Iconographia Diatomologica 23: 743-747, 3 photogr.

GRAHAM, L.R. 2016. Lysenko’s ghost: Epigenetics and Russia. Harvard University Press, Cambridge, 200pp.

HARLAND, S.C. 1954. Nicolai Ivanovitch Vavilov. 1885-1942. Obituary Notices of Fellows of the Royal Society 9: 259-226. 
HARRIS, D.R. 1990. Vavilov's concept of centres of origin of cultivated plants: its genesis and its influence on the study of agricultural origins. Biological Journal of the Linnean Society 39: 7-16.

MukhinA, V.V., KazArinA, G.K., \& MARKovA, A K. 2005. Shkola A.P. Zhuze. [The school of A.P.Zhuze]. Priroda 7: 73-79 [In Russian].

PRINGLE, P. 2008. The Murder of Nikolai Vavilov. Simon \& Schuster, 370pp.

REIMER, C.W. 1959. The diatom genus Neidium. I. New species, new records and taxonomic revisions. Proceedings of the Academy of Natural Sciences of Philadelphia 111: 1-35. SAPP, J, CARRAPIÇO, F. \& ZOLOTONOSOV, M. 2002. Symbiogenesis: The hidden face of Constantin Merezhkowsky. History and Philosophy of the Life Sciences 24: 413-440

SELLING, O.K. 1962. Robert Wilhelm Kolbe (10. Januar 1882 - 9. Marz 1960). Nova Hedwigia 4: 275-298.

SHAW, D.J.B. \& OLDFIELD, J.D. 2015. Soviet geographers and the Great Patriotic War, 19411945: Lev Berg and Andrei Grigor’ev. Journal of Historical Geography 47: 40—49.

SIEMIŃSKA, J. 2007. Polscy badacze okrzemek. Wiadomości Botaniczne 51(1/2): 27-43.

SkVortzov, B.V. 1917a. Materialy po flory vodoroslej Aziatskoj Rossii. I. Vodorosli iz' Akutskoj oblasti. [Contributions a la flore des algues de la Russie d'Asie. I. Algues de la province de Jakoutsk.] Zhurnal Russkogo Botanicheskogo Obshchestva pri Akademii Nauk 2: 10-12 [French summary, p. 19].

Skvortzov, B.V. 1917b. Materialy po flory vodoroslej Aziatskoj Rossii. IV. Vodorosli verhov'ev" raki zei Amurskoj oblasti. [Contributions a la flore des algues de la Russie d'Asie. IV. Algues des sources du fleuve Zeja (Province Amourienne)]. Zhurnal Russkogo Botanicheskogo Obshchestva pri Akademii Nauk 2: 1 17-120 [French summary, p. 128].

Skvortzov, B.V. 1918. Materialy po flory vodoroslej Aziatskoj Rossii. VII. Perbya svydynia o fitoplanktony r. Amura. [Contributions a la flore des algues de la Russie d'Asie. VII. Notions 
preliminaires sur le phytoplancton de d' Amour. ] Zhurnal Russkogo Botanicheskogo Obshchestva pri Akademii Nauk 3: 1-9 [French summary, p. 21].

SkVORTZOV, B.V. 1937a. Bottom diatoms from Olhon Gate of Baikal Lake, Siberia. Philippine Journal of Science 62: 293-377.

Skvortzov, B.V. 1937b. Neogene Diatoms from eastern Shantung. Bulletin of the Geological Society of China 17(1-4): 193-204.

Skvortzov, B.V. 1946. Novye i malo izvestnye vidy Algae, Flagellatae, Phycomicetae iz Azii, Ameriki, Afriki, a takzhe s ostrovov Japonii i Ceylona, opisannye v 1931-45 g.g. s 18 tablitsami risunkov. [Species novae et minus cognitae Algarum, Flagellatarum et Phycomicetarum Asiae, Africae, Americae et Japoniae nec non Ceylon anno 1931-45 descripto et illustrato per tab. 1-18.] Zapiski Kharbinskogo Obshchestva Estestvoispytateley i Etnografov [Proceedings of the Harbin Society Natural History and Ethnography] 2: 1-34 [In Russian].

Skvortzov, B.V. 1971. Diatoms from Yenisei River and its tributaries, middle part of Siberia, western Asia. Philippine Journal of Science 98(1): 57-113.

Skvortzov, B.V. 1974 (December). Notes and papers printed from 1917-1970 (Bibliography). Quarterly Journal of Taiwan Museum 27(3-4): 389-417.

SKVORTZOV, B.V. 2012. New and little known fresh- and brackish water diatoms chiefly from Eastern part of Asia and their geographical distribution. Iconographia Diatomologica 23: 749-861, 499 figs., 1 map.

SkVORTZOV, B.V. \& NODA, M. 1970. New and little-known varieties of Pinnularia viridis (Nitz.) Ehr. in eastern and Arctic Europe and Asia. Science Reports of Niigata University, Ser. D (Biology) 7: 37-47.

SkVORTZOV, B.V. \& NodA, M. 1971. On Recent and fossil freshwater diatoms from Japan I. Science Reports of Niigata University, Ser. D (Biology) 8: 1-11. 
SkVORTZOV, VASILIY AlEXANDROVICH n.d. Unpublished ms.

UEDO, H. 1940. A catalogue of freshwater diatoms of Manchoukuo cited from Skvortzov's papers. Report of the Limnobiological Survey of Kwantung and Manchoukuo [not seen].

VAVILOV, N. I., 1926. Studies on the Origin of Cultivated Plants. Leningrad, Institut Botanique Appliquié et d’Amélioration des Plantes, 248pp.

WILLIAMS, D.M. 2004. On diatom endemism and biogeography: Tetracyclus and Lake Baikal Endemic Species. Proceedings of the $17^{\text {th }}$ International Diatom Symposium, BioPress Ltd, pp. 433-459.

WiLliams, D.M. 2011. Additions to and comments on the bibliography of Robert Ross. Diatom Research 26: 317-318.

WILLIAMS, D.M. \& REID, G. 2001. A bibliography of the scientific work of Boris V. Skvortzov (1896-1980) with commentary on the publications concerning diatoms (Bacillariophyta). Bulletin of the British Museum Natural History, Botany Series 31(2): 89-106.

WiLliams, D.M. \& REID, G. 2005. The Sino-Siberian distribution of Eunotia clevei and its relatives, from Lake Baikal to the Mekon Delta: the union of taxonomy, biogeography and ecology. Memoirs of the California Academy of Sciences 56:179-187.

WisŁouch, S.M. \& KolBE, R.W. 1916. Novye diatomovye vodorosli iz vodoemov Rossii. (Neue Diatomeen aus den gewässern von Russland). Zhurnal Mikrobiologii, Leningrad (Zeitschrift fur Mikrobiologie, Petrograd) 3: 263-275.

WisŁouch, S.M. \& KolBE, R.W. 1927. Materialy po diatomovym Onezhskogo i Lososinskogo ozer. (Beiträge zur Kenntnis der Kieselalgen der Onegaund Lossosinskoje-Seen). Trudy Olonetzkoi nauchnoi ekspeditsii, gosudarstvennyi gidrologicheskii institute 5(1): 3-66. 


\section{Appendix}

Manuscript material held at the Natural History Museum, London

\section{Correspondence:}

$\begin{array}{lll}\begin{array}{l}\text { Skvortzov - Mills, F.W. } \\ \text { Skvortzov - “The Editor of }\end{array} & \text { Harbin, China } & {\left[22^{\text {nd }} \text { March 1957] }\right.} \\ \text { the Botanical Journal” } & \text { Harbin, China } & {\left[22^{\text {nd }} \text { March 1957] }\right.} \\ \text { Skvortzov - Ross, R. } & \text { Harbin, China } & {\left[18^{\text {th }} \text { June 1957] }\right.} \\ \text { Skvortzov - Ross, R. } & \text { Harbin, China } & {\left[6^{\text {th }} \text { July 1957 }{ }^{14}\right]} \\ \text { Skvortzov - Ross, R. } & \text { Harbin, China } & {\left[15^{\text {th }} \text { July 1957 }{ }^{15}\right]} \\ \text { Skvortzov - Ross, R. } & \text { Harbin, China } & {\left[27^{\text {th }} \text { January 1958] }\right.} \\ \text { Skvortzov - Ross, R. } & \text { Hongkong } & {\left[20^{\text {th }} \text { July 1962 }\right]} \\ \text { Skvortzov - Ross, R. } & \text { Sao Paulo, Brazil } & {\left[8^{\text {th }} \text { November 1962] }\right.} \\ \text { Skvortzov - Ross, R. } & \text { Sao Paulo, Brazil } & {\left[8^{\text {th }} \text { August 1963] }\right.} \\ \text { Skvortzov - Ross, R. } & \text { Sao Paulo, Brazil } & {\left[30^{\text {th }} \text { September 1963] }\right.} \\ \text { Skvortzov - Ross, R. } & \text { Sao Paulo, Brazil } & {\left[26^{\text {th }} \text { March 1965] }\right.} \\ \text { Skvortzov - Ross, R. } & \text { Sao Paulo, Brazil } & {\left[16^{\text {th }} \text { July 1965] }\right.}\end{array}$

\footnotetext{
${ }^{14}$ This letter includes descriptions of Pinnularia viridis varieties (for 'algological notes n. 2') and of Amphora species documented in the mss section here but never published.

${ }^{15}$ This letter was to alert Ross to two further letters to follow that included the ms pages for Algological Notes 2-7 documented here.
} 


\begin{tabular}{|c|c|c|}
\hline Skvortzov - Ross, R. & Sao Paulo, Brazil & [18 ${ }^{\text {th }}$ January 1966$]$ \\
\hline \multicolumn{3}{|l|}{ as “The Editor of Royal } \\
\hline \multicolumn{3}{|l|}{ Microscopical Society...” } \\
\hline Ross, R - Secretary of the & & [23 ${ }^{\text {rd }}$ May 1957] \\
\hline \multicolumn{3}{|l|}{ Royal Microscopical Society } \\
\hline Ross, R - Skvortzov, B. & & [31 July 1962] \\
\hline Skvortzov, B. - Fryxell, G. & Sao Paulo, Brazil & [17 $7^{\text {th }}$ October 1974 , photocopy] \\
\hline \multirow[t]{4}{*}{ Sormus, Laine ${ }^{16}-$ Thomasson, K. ${ }^{17}$} & Sao Paulo, Brazil & [ $4^{\text {th }}$ November 1975 , photocopy \\
\hline & & from the Freshwater Biological \\
\hline & & Association; an enquiry about \\
\hline & & Skvortzov's reprints] \\
\hline
\end{tabular}

\section{Manuscripts:}

The list of diatom[s] samples collected in Brasil by B.V. Skvortzov (Sao Paulo, Brasil, Jardin

Europa Rua Iquatemi 1074 app. 4) in 1963, 2 pp., along with 50 packets of dried material.

Bibliography. B.V. Skvortzov (Sao Paulo, Brasil). Notes and Papers from 1917—1970

(subsequently published as Skvortzow, 1974).

The Latin for algological notes n. 2:-New and little known varieties of Pinnularia viridis, with 8 figs in text, 2 pp. ${ }^{18}$

The Latin for algological notes n. 3:-New and little known varieties of Pinnularia nobilis, with 6 figs in text, 2 pp.

The Latin for algological notes n. 4:-Pinnularia major (Kutz.) Cl. and its varieties from Northern Europe and Eastern Asia with 8 figs in text, 2 pp. ${ }^{19}$

\footnotetext{
${ }^{16}$ A Brazilian phycologist.

${ }^{17}$ Kuno Thomasson (1923 - 2007) was a Swedish phycologist, originally from Estonia.

${ }^{18}$ Some of these new varieties were published in Skvortzov and Noda (1970); see footnote 1.
} 
The Latin for algological notes n. 5:-New types of Pinnularia's from Eastern Asia with 7 figs in text, 3 pp. ${ }^{20}$

[Species descriptions for Amphora], 2 plates, 5 pp.

The Latin for algological notes n. 6:-On new varieties of Pinnularia dactylus Eh. from Northern Europe and Eastern Asia with 5 figs, 1 p.

The Latin for algological notes n. 7:--Some new Pinnularia with [...] median line, 2 pp.

Notes on freshwater Flagellatae. VIII. Genus Chlorogonium Ehrenb. (Volvocales), Chlamydomonadaceae) from environs of Harbin, Northern Manchuria, China, with 13 figures in text, 2 pp.

Notes on freshwater Flagellatae. VIII. IX. Four New Species of the genus Thorakomonas Korsh. (Volvocales), Chlamydomonadaceae) from Eastern Asia, with 4 figures in text, 2 pp.

\footnotetext{
${ }^{19}$ See Skvortzov (1971).

${ }^{20}$ This note is also as a typed version. See Skvortzov (1971).
} 


\section{Figure legends}

Figure 1: Vasiliy Aleksandrovich Skvortzov (Harbin 1922)

Figure 2: Vasiliy Filippovich Skvortzov

Figure 3: The Skvortzov family coat of arms

Figure 4: The father, mother, sisters and brother of Boris Skvortzov (Boris is the second from the right)

Figure 5: Boris Skvortzov in St. Petersburg University

Figure 6: Boris Skvortzov studying the flora of Manchuria

Figure 7: Zinoviya Petrovna, Boris Skvortzov’s wife

Figure 8: Boris Skvortzov’s family in Harbin

Figure 9: Skvortzov's family home in Harbin

Figure 10: The remains of the monuments of the Uspenskoe Cemetery, Harbin (the gravestone of Boris Skvortzov’s parents)

Figure 11: Boris Skvortzov in Brazil, São Paulo (1978-1979) 